\title{
COMPUTERS FOR BRITISH RESEARCH
}

THE formation of the Computer Board by the Secretary of State for Education and Science has not brought a great wave of congratulation from British universities and research establishments, but instead a tendency to complain that it is not enough, and not soon enough. Even the fact that Mr. Anthony Crosland has somehow persuaded the Treasury to part with $£ 3$ million a year at a time like this has not silenced all the critics. This may therefore be the right time to ask what are the prospects for computers in the universities and other research establishments in Britain.

The origins of current arguments about the scale on which computing facilities should be provided in British universities go back to the appointment in March 1965 of a working group under Prof. B. H. Flowers. The working group itself was born of discussions within the Council for Scientific Policy (under Sir Harrie Massey), and between the council and the University Grants Committee. Professor Flowers is himself a member of Sir Harrie Massey's committee. His working group moved quickly, and reported to the Minister in July 1965. The report was eventually published in December 1965 , together with a general statement by the British Government that its recommendations had won "general approval".

The essential feature of the recommendations was that computing facilities at universities and research establishments should be integrated into a regional framework, with universities and research councils having access as of right to whatever facilities are available. Edinburgh, Manchester and London were singled out as regional centres, to be equipped with powerful computers (rented in the first instance from suppliers in the United States) with the possibility that other universities in the Midlands and South-West might graduate into regional centres later on. It was also argued that money should be spent immediately on making the fullest use of the English Electric $K D F^{\prime} 9$ computers at seven British universities.

Finally, the working group argued the case for spending money on a number of installations at a further twentyone institutions, either to improve existing machines or to buy new ones. All these developments, according to the report, should be carried out on a regional basis, with universities and the research institutions responsible to the five research councils having a right to use all nearby computers and the regional computing centre.

The estimates in the Flowers Report on future demand for computing power are based on estimates by the universities themselves, though the working group did on some occasions point out that demand was likely to grow more quickly than universities themselves foresaw. Its estimates are, however, supported by the experience of large university installations in the United States where the demand for computer time appears to have been doubling every year for some years now. Taking the computing power of an IBM 7090 as a yardstick (which means that an improved $K D F 9$ with a $36 K$ store is equivalent to $1 \cdot 2$ 7090 machines), the group estimated that its proposals would increase the computer power of British research institutions from roughly 15 units in March 1965 to roughly 135 in March 1970.

The response of the British Government to these proposals has been surprisingly openhanded, given the economic difficulties of the past twelve months. The total cost of the programme has, however, been stretched out over six years and not five. Orders for the improvements intended at the $K D F$ installations and the other twentyone universities with less sophisticated equipment have already been placed, chiefly through a panel of the University Grants Committee under Sir Willis Jackson. Moreover, a regional centre at Edinburgh has already been formed.

Why, then, has the whole project encountered widespread criticism in recent weeks? Three separate lines of complaint are evident. First, people complain of the delay, both in setting up the computer board and in implementing the other proposals of the Flowers Group. Then there is a complaint that in the interval between the report a year ago and the present, multiple access computer systems have been shown in the United States not to be fanciful experimental tools but essential building bricks in any modern computer system, so that the degree of integration implicit in the Flowers proposals is now inadequate. Finally, it is held that the preoccupation of the Flowers Report with the needs of universities and research councils has made even sharper the gulf between the comparatively academic affairs of the Department of Education and Science and the more industrial preoccupations of the Ministry of Technology.

The nub of the argument on delay is that the investments proposed by the Flowers Group were intended to be spent in the period July 1965 to July 1970, while the present plans of the Government would start a year later and finish two years later. Moreover, the criticism continues, the delay in the setting up of the Computer Board has meant further delays in beginning serious work on the proposals. The rejoinder to this is that Sir Willis Jackson and his panel have been hard at work spending their $£ 3$ million a year on the improvement of university computing, and that the panel has even gone somewhat further than the Flowers Group foresaw by placing a firm order for an English Electric multiple access computer at Edinburgh for delivery in roughly two years.

On the character of the computing system to be developed there seems to be genuine disagreement. There are those who argue that the time has now come for a closely integrated system of computers within a national network, with access by means of individual consoles. It is held that experience in the United States, and the character of forward planning in France, make such a system feasible and desirable in Britain. On the other hand are those who argue that the experience with systems such as Project MAC at the Massachusetts Institute of Technology (Nature, 209, 1161;1966) is not yet sufficient to demonstrate that a multiple access system on a national scale will really work. In any event, they argue, the universities and research establishments will always need a much more personal form of access to computers, for their need of these machines is not simply their need of computation but also their need of opportunities for teaching and research.

The complaint about the gulf between science and technology is linked with the way in which the Ministry of Technology is apparently pursuing an independent policy in the development of computing centres. Thus it has recently established a National Computing Centre at the Manchester College of Science and Technology, with Professor Gordon Black as director. The centre will be a more or less commercial venture, drawing support by way of fees from industrial manufacturers and users of computers, and also by means of grants from the Ministry of Technology. The decisive role of the centre can be in the development of software both for use with machines now being developed by British companies and for improving the efficiency of systems already in use. 